\title{
The effects of Myristica fragrans seed meal and Syzygium aromaticum leaf meal dietary supplementation on growth performance and oxidative status of broiler chicken
}

\author{
Olufemi Adesanya Adu ${ }^{1,2}$, Francis Ayodeji Gbore ${ }^{1}$, Olugbenga David Oloruntola ${ }^{*^{*}}$ (D), \\ Andrew Bamidele Falowo ${ }^{1}$ and Olumuyiwa Joseph Olarotimi ${ }^{1}$
}

\begin{abstract}
Background: The study examined the effects of Myristica fragrans seed meal (MSM) and Syzygium aromaticum leaf meal (SLM) dietary supplementation on the growth performance, health status, and meat quality of broiler chicken.

Methods: A total of two hundred and forty 1-day-old broiler chickens were assigned the four dietary treatments: Diet 1/control (no supplementation), Diet 2 (0.25\% MSM), Diet 3 (0.25\% SLM), and Diet 4 (0.25\% MSCM, i.e., MSM + SLM 1:1). The birds were fed ad libitum throughout the feeding trial.

Results: The dietary supplementation of $0.25 \%$ MSCM resulted in higher body weight gain and lowered feed conversion ratio $(p<0.05)$ at the finisher stage and overall period, while feed intake was not statistically affected $(p>0.05)$ across the treatments. The dietary inclusion of MSM, SLM, and MSCM did not significantly influence carcass traits, relative internal organ weights, and haematological indices of the broiler chicken $(p>$ $0.05)$ except mean cell volume and mean cell haemoglobin content $(p<0.05)$. The result further revealed that broilers fed diets supplemented with MSM, SLM, and MSCM had higher $(p<0.05)$ serum catalase, glutathione peroxidase and lowered serum cholesterol compared with control. The meat cholesterol levels and lipid peroxidation of the birds were significantly $(p<0.05)$ reduced, while glutathione peroxidase was increased by dietary MSM, and MSCM supplementation.
\end{abstract}

Conclusion: The MSCM supplementation at $0.25 \%$ enhanced the body weight gain, improved serum, and meat glutathione peroxidase and catalase but reduced the broiler's meat cholesterol level and lipid oxidation.

Keywords: Herb and spice phyto-additives, Performance, Haematology, Antioxidant status, Meat quality

\section{Background}

The recognition and utilization of herbs, spices, and their extracts as natural feed additives in poultry diets have increased in recent years due to their inherent multi-bioactive properties and ability to enhance performance traits, reduce pathogenic bacteria, and

\footnotetext{
* Correspondence: oloruntoladavid@gmail.com;

olugbenga.oloruntola@aaua.edu.ng

${ }^{1}$ Animal Science Department, Adekunle Ajasin University, Akungba Akoko, Nigeria

Full list of author information is available at the end of the article
}

decrease antibiotic residues in meat and egg products (Dhama et al. 2015). In comparison to antibiotic growth promoters, herbs and spices are economical and readily available, edible and low in toxicity, rich in nutrients, and useful in improving the health of animals and consumers (Dhama et al. 2015). Applications of herbs in poultry diets have been reported to stimulate endogenous antioxidants, facilitate nutrient metabolism and improve meat quality by lowering cholesterol content and inhibiting peroxidation (Oloruntola et al. 2018; 
Oloruntola et al. 2019). Interestingly, Myristcan fragrans and Syzygium aromaticum plants are among the herbs and spices with a lot of potentials that can be utilized as feed additives in poultry production.

Myristica fragrans, also known as nutmeg, is an aromatic perennial tropical plant with a characteristic scent that possesses multiple medicinal and antioxidant properties (Periasamy et al. 2016). Its seed is widely used as herb and spice in many traditional and conventional food industries around the world (Olaleye et al. 2006) The seed contains phenolic, flavonoid, and other important bioactive compounds (Zakaria et al. 2015; Yakaiah et al. 2019). Nutritionally, nutmeg is rich in energy, carbohydrates, proteins, dietary fibre, vitamins (Vitamins A, $\mathrm{C}$, and E) and minerals (Agbogidi and Azagbaekwe 2013). The potential phytochemicals in Myristica fragrans plant have been reported to exert antioxidant, antimicrobial, antipain, antiobesity, and hepatoprotective activities in biological systems (Morita et al. 2003; Olaleye et al. 2006; Agbogidi and Azagbaekwe 2013; Yakaiah et al. 2019). The dietary administration of Myristica fragrans extracts was reported to inhibit lipid digestion, absorption and accumulation of adipose tissue in the rat (Yakaiah et al. 2019), reduce cholesterol level in rabbits (Sharma et al. 1995), and prevent liver damage in the rat (Morita et al. 2003). Inclusion of Myristica fragrans seed extracts at $1.25,2.50$, and $5.00 \%(\mathrm{~g} / \mathrm{ml})$ has been demonstrated to improve physicochemical properties and oxidative stability of raw beef during 3-week cold storage at $-18^{\circ} \mathrm{C}$ compared with control (Zakaria et al. 2015). Despite the efficacy of Myristica fragrans seed in muscle food preparation, little or no work has been done on its dietary application in poultry production.

Syzygium aromaticum (clove) is an aromatic evergreen plant commonly used in the preparation of curry powder. It is very rich in many bioactive compounds including eugenol (72-90\%), flavonoids, and triterpenoids (Bhowmik et al. 2012). Nutritionally, it contains vitamin A (retinol); beta-carotene; and vitamins $\mathrm{K}, \mathrm{B} 6, \mathrm{~B} 1$, and $\mathrm{C}$ (Nadkarni, 2000; Dorman et al., 2000). Syzygium aromaticum has been used to treat indigestion, parasitic infestations, cough, and blood impurities (Bhowmik et al. 2012). Many reports have shown that it contains antimicrobial, antioxidant, antiviral, and anticancer agents (Bhowmik et al. 2012; Sulieman et al. 2007). Application of Syzygium aromaticum at a high concentration as a growth promoter in the animal diet has been successfully reported although with contrasting results particularly on growth performance. Mahrous et al. (2017) in a study found that supplementation of Syzygium aromaticum powder at 1.0 and $1.5 \mathrm{~g} / \mathrm{kg}$ diets significantly decreased body weight gain but increased feed conversion ratio and protein efficiency ratio compared with the control treatment. Similarly, Al-Mufarrej et al. (2019a, 2019b) reported that dietary inclusion of Syzygium aromaticum powder at $30,40,50$, and $60 \mathrm{~g} / \mathrm{kg}$ significantly reduced the body weight gain and increased necrotic enteritis of broiler chickens compared with control. On the other hand, Mahrous et al. (2017) found that the inclusion of clove powder at 1.0 and $1.5 \mathrm{~g} / \mathrm{kg}$ diets did not affect growth performance parameters but improved the health and meat qualities of broiler chickens. It is therefore important to examine the supplementation of Syzygium aromaticum at low concentration on broiler chicken performance. The objective of this study was to determine the effects of Myristica fragrans seed meal and Syzygium aromaticum leaf meal dietary supplementation on broiler chicken.

\section{Materials and methods \\ Collection and processing of plant samples}

The dry seeds of Myristica fragrans seeds and dry Syzygium aramaticum leaves were procured from the local markets in southwestern Nigeria, ground to about $100 \mu \mathrm{m}$ with a hammer mill to produce Myristica fragrans seed meal (MSM) and dry Syzygium aramaticum leaf meal (SLM), respectively. Equal quantity (1:1) of MSM and SLM were mixed to form Myristica fragrans seeds and Syzygium aramaticum leaf meal composite $\operatorname{mix}(\mathrm{MSCM})$.

\section{Analysis of phytogens}

The MSM and SLM were analyzed for phenol (Ignat et al. 2013), saponin (Brunner 1984), terpenoids (Sofowora 1993), flavonoids (Bohm and Kocipai-Abyazan 1994), and 2,2-diphenyl-1-picrylhydrazy hydrate (Gyamfi et al. 1999).

\section{Animal management and experimental design}

The broiler chickens' basal diet was prepared for the starter phase and finisher phase following the NRC (1994) nutritional recommendations (Table 1). At each of the production phases, the basal diet was divided into four equal parts and named diets 1 to 4 . Diet 1 (control) has $0 \%$ supplementation, while diets 2,3 , and 4 were supplemented with $0.25 \%$ MSM, SLM, and MSCM, respectively.

Two hundred and forty 1-day-old Cobb 500 broiler chickens were randomly assigned to four experimental diets (60 birds/experimental diet; 10 birds/replicate) using a completely randomized design. The experimental pen temperature was regulated and maintained at $31^{\circ} \mathrm{C} \pm 2$ for the 14 days and gradually reduced by $2{ }^{\circ} \mathrm{C}$ after each consecutive 7 days until the experimental house temperature was $26^{\circ} \mathrm{C} \pm 2$. The lighting duration was $23 \mathrm{~h}$ per day. The birds were fed ad libitum. 
Table 1 Composition of the experimental diets

\begin{tabular}{lll}
\hline & Starter feed & Finisher diet \\
\hline Ingredients (\%) & 52.35 & 59.35 \\
Maize & 7.00 & 0.00 \\
Maize bran & 0.00 & 6.00 \\
Rice bran & 30.00 & 24.00 \\
Soybean meal & 3.00 & 3.00 \\
Fish meal & 3.00 & 3.00 \\
Soy oil & 3.00 & 3.00 \\
Bone meal & 0.50 & 0.50 \\
Limestone & 0.25 & 0.25 \\
Lysine & 0.30 & 0.30 \\
Methionine & 0.30 & 0.30 \\
Salt & 0.30 & 0.30 \\
Premix & & \\
Analyzed composition (\%) & 22.18 & 20.03 \\
Crude protein & & 0.73 \\
Calculated composition (\%) & 3018.89 & 3108.10 \\
Metabolizable energy (Kcal/kg) & 1.36 & 1.24 \\
Lysine & 0.68 & 0.66 \\
Methionine & 1.01 & 0.99 \\
Calcium & 0.70 & \\
Available phosphorus & & \\
\hline
\end{tabular}

Growth performance, slaughtering procedures, collection of blood samples, and carcass analysis

The experimental birds' body weight and feed intake were determined and recorded on a weekly interval. The feed conversion ratio was calculated as the ratio of feed intake by the birds to their weight gain. On day 56 of the experiment, 3 experimental birds per replicate were labelled and sacrificed as earlier described by Oloruntola et al., (2019). The jugular veins at the birds' neck region were cut with a clean and sharp stainless knife. Blood was collected into a plain blood sample bottle for serum antioxidant enzymes and serum enzymes and also into EDTA bottle haematological studies, respectively. The blood in the plain bottles was spined and its serum decanted into another set of plain well-labelled bottles and frozen at $-20{ }^{\circ} \mathrm{C}$ prior analysis. The haematological indices were determined within $120 \mathrm{~min}$ of post-collection (Shastry 1983). The concentrations of serum enzymes were analyzed on a Reflectron ${ }^{\circledR}$ Plus 8 C79 (Roche Diagnostic, GombH Mannheim, Germany), using kits. The serum antioxidant enzymes-i.e. superoxide dismutase (Misra and Fridovich 1972), catalase (Aebi 1974), and glutathione peroxidase (Rotruck et al. 1973)-were determined. The selected slaughtered birds were dressed and weighed. The dressed percentage of the birds was calculated as a percentage of the slaughtered weight. About $100 \mathrm{~g}$ of the breast meat was cut for determination of the level of the lipid peroxidation (Botsoglou et al. 1994), meat cholesterol (Allain et al. 1974), catalase activity (Hadwan and Khabt 2018), and glutathione peroxidase activity (Cichoski et al. 2012).

\section{Data analysis}

The model, $T s m=\mu+\alpha s+\beta s m$, was used in this experiment, where Tsm is any of the response variables; $s$ is the overall mean; $\alpha s$ is the effect of the sth treatment ( $T$ = diets $1,2,3$, and 4 ); and $\beta s m$ is the random error due to experimentation. The data were subjected to oneway ANOVA using SPSS version 20. The differences among the experimental treatment means were determined $(P<0.05)$ by the Duncan multiple range test of the same package.

\section{Results}

Antioxidant activity and phytochemical composition of Myristical fragrans seed meal (MSM) and Syzygium aromaticum leaf meal (SLM)

Table 2 shows the result of the phytochemical composition and antioxidant activity of Syzygium aromaticum leaf meal (SLM) and Myristica fragrans seed meal (MSM). The phytochemical composition analysis of MSM revealed higher saponin $(43.35 \pm 0.72 \mathrm{mg} / \mathrm{g})$, flavonoid $(2.06 \pm 0.05 \mathrm{mg} / \mathrm{g})$, phenol $(26.27 \pm 0.03 \mathrm{mg} / \mathrm{g})$, and terpenoid $(107.85 \pm 0.75 \mathrm{mg} / \mathrm{g})$ contents than SLM. However, SLM had higher antioxidant (2,2-diphenyl-1picryl-hydrazyl-hydrate, DPPH) free radical scavenging activity $(80.55 \pm 0.07 \%)$ than MSM $(21.58 \pm 0.42 \%)$.

\section{Performance of broiler chickens}

Table 3 shows the effects of dietary supplementation of Syzygium aromaticum leaf meal (SLM), Myristica fragrans seed meal (MSM), and their composite mix (MSCM) on the growth performance of broiler chickens at starter and grower phases and overall period. At the starter phase, the study revealed no significant difference

Table 2 Antioxidant activity and phytochemical composition of Syzygium aromaticum leaf meal and Myristica fragrans seed meal

\begin{tabular}{lll}
\hline Parameter & $\begin{array}{l}\text { Syzygium aromaticum leaf } \\
\text { meal }\end{array}$ & $\begin{array}{l}\text { Myristica fragrans seed } \\
\text { meal }\end{array}$ \\
\hline Saponin $(\mathrm{mg} / \mathrm{g})$ & $19.17 \pm 0.18$ & $43.35 \pm 0.72$ \\
$\begin{array}{l}\text { Flavonoid }(\mathrm{mg} / \\
\text { g) }\end{array}$ & $0.04 \pm 0.00$ & $2.06 \pm 0.05$ \\
Phenol (mg/g) & $4.24 \pm 0.58$ & $26.27 \pm 0.03$ \\
$\begin{array}{l}\text { Terpenoid (mg/ } \\
\text { g) }\end{array}$ & & $107.85 \pm 0.79 \pm 0.03$ \\
DPPH (\%) & $80.55 \pm 0.07$ & $21.58 \pm 0.42$
\end{tabular}

$\overline{D P P H}$ 2,2-diphenyl-1-picryl-hydrazyl-hydrate 
$(P>0.05)$ in the initial body weight, body weight gain (BWG), feed intake (FI), and feed conversion ratio (FCR) across the treatments. However, at the grower phase and overall period, broiler chickens fed diets supplemented with MSCM had higher BWG and better FCR $(P<0.05)$ than the control group, while there was no significant difference in feed intakes $(P>0.05)$ across the treatments. In general (during the overall period), birds on diet $0.25 \%$ MSCM had the highest BWG (3516.05 g) followed by those on diets $0.25 \%$ MSM (2875.27 g) and $0.25 \%$ SLM $(2845.00 \mathrm{~g})$ and least for the bird on control diet (2815.40). The value of FCR was least in birds fed with diet containing $0.25 \%$ MSCM (1.39) and highest in the control group (1.78).

\section{Carcass traits and relative internal organs of broiler chickens}

As presented in Table 4, supplementation of MSM, SLM, and MSCM did not significantly influence the carcass traits (slaughtered weight, dressed weight, and dressing percentage) and relative internal organ weights (liver, heart, lung, pancreas, gall bladder, spleen, gizzard, and proventriculus) of the broiler chicken $(P>0.05)$.

\section{Haematological indices of broiler chickens}

The haematological indices of the broiler chickens fed with diet containing Myristica fragrans seed meal (MSM), Syzygium aromaticum leaf meal (SLM), and their composite mix (MSCM) are shown in Table 5. The packed cell volume, red blood cells, haemoglobin concentration, mean cell haemoglobin concentration, and white blood cells of broiler chickens were not significantly $(P>0.05)$ affected by MSM, SLM and MSCM supplementation compared with control. However, the mean cell volume and mean cell haemoglobin content of the broiler chicken were significantly influenced $(P<$ 0.05 ) by MSM, SLM, and MSCM supplementation, with broiler chickens fed with diet containing 0.25\% SLM having the highest mean cell volume $(161.81 \mathrm{fl})$ and mean cell haemoglobin $(53.93 \mathrm{pg})$, while birds on control diet had the lowest mean cell volume $(112.50 \mathrm{fl})$ and mean cell haemoglobin $(36.96 \mathrm{pg})$.

\section{The serum metabolites and serum antioxidant enzyme of the broiler chickens}

Table 6 shows the serum metabolites and antioxidant enzymes of the broiler chickens fed with diet containing MSM, SLM, and MSCM. The result of serum metabolites revealed that creatinine, aspartate aminotransferase, and alanine aminotransferase concentrations of the broiler chicken were not significantly $(P>0.05)$ influenced by MSM, SLM, and MSCM supplementation compared with control. The serum cholesterol level was significantly $(P<$ $0.05)$ lower in birds receiving diets supplemented with MSM, SLM, and MSCM compared with the bird receiving control diet $(7.03 \mu \mathrm{mol} / \mathrm{l})$. The concentration of serum catalase and glutathione peroxidase was significantly $(P<$ $0.05)$ higher in birds fed with diet containing MSM, SLM, and MSCM than the control group, while there was no significant $(P>0.05)$ effect of MSM, SLM, and MSCM supplement on serum superoxide dismutase concentration of broiler chickens compared with control.

Table 3 Effects of the phytogenic supplements on the performance of broiler characteristics of broiler chickens

\begin{tabular}{|c|c|c|c|c|c|}
\hline Parameters & $\begin{array}{l}\text { Diet } 1 \\
\text { Control }\end{array}$ & $\begin{array}{l}\text { Diet } 2 \\
0.25 \% \text { MSM }\end{array}$ & $\begin{array}{l}\text { Diet } 3 \\
0.25 \% \text { SLM }\end{array}$ & $\begin{array}{l}\text { Diet } 4 \\
0.25 \% \text { MSCM }\end{array}$ & $P$ value \\
\hline \multicolumn{6}{|c|}{ Starter phase (1 to 28 days) } \\
\hline IBW (g/bird) & $43.09 \pm 1.65$ & $44.59 \pm 0.14$ & $43.80 \pm 0.51$ & $44.13 \pm 0.23$ & 0.68 \\
\hline BWG (g/bird) & $991.10 \pm 95.79$ & $983.84 \pm 54.80$ & $984.58 \pm 88.58$ & $1226.47 \pm 27.69$ & 0.11 \\
\hline $\mathrm{FI}$ (g/bird) & $1444.36 \pm 31.38$ & $1346.54 \pm 45.94$ & $1361.72 \pm 51.60$ & $1386.46 \pm 31.76$ & 0.40 \\
\hline FCR & $1.49 \pm 0.17$ & $1.38 \pm 0.11$ & $1.39 \pm 0.88$ & $1.13 \pm 0.04$ & 0.21 \\
\hline \multicolumn{6}{|c|}{ Grower phase (29 to 56 days) } \\
\hline BWG (g/bird) & $1824.30 \pm 109.33^{b}$ & $1891.43 \pm 88.00^{b}$ & $1860.41 \pm 42.97^{b}$ & $2289.58 \pm 90.23^{\mathrm{a}}$ & 0.01 \\
\hline $\mathrm{Fl}(\mathrm{g} / \mathrm{bird})$ & $3561.04 \pm 166.10$ & $3433.73 \pm 142.41$ & $3399.98 \pm 20.86$ & $3510.70 \pm 107.32$ & 0.78 \\
\hline FCR & $1.95 \pm 0.03^{\mathrm{a}}$ & $1.81 \pm 0.03^{\mathrm{a}}$ & $1.82 \pm 0.03^{\mathrm{a}}$ & $1.54 \pm 0.10^{b}$ & 0.01 \\
\hline \multicolumn{6}{|c|}{ Overall (1 to 56 days) } \\
\hline BWG (g/bird) & $2815.40 \pm 194.64^{b}$ & $2875.27 \pm 90.86^{b}$ & $2845.00 \pm 129.35^{b}$ & $3516.05 \pm 72.62^{a}$ & 0.02 \\
\hline $\mathrm{FI}$ (g/bird) & $5005.41 \pm 176.99$ & $4780.28 \pm 155.18$ & $4761.70 \pm 68.44$ & $4897.16 \pm 123.38$ & 0.58 \\
\hline FCR & $1.78 \pm 0.08^{\mathrm{a}}$ & $1.66 \pm 0.06^{\mathrm{a}}$ & $1.67 \pm 0.05^{\mathrm{a}}$ & $1.39 \pm 0.06^{\mathrm{b}}$ & 0.02 \\
\hline
\end{tabular}

MSM Myristica fragrans seed meal, SLM Syzygium aromaticum leaf meal, MSCM Myristica fragrans seed meal and Syzygium aromaticum leaf meal composite mix (1:1), IBW initial body weight, BWG body weight gain, FI feed intake, FCR feed conversion ratio, SEM standard error of the mean

${ }^{\mathrm{ab}}$ Means within a row with different letters and are significantly different $(P<0.05)$ 
Table 4 Effects of phytogenic supplements on carcass and relative internal organ weights (\% slaughtered weight) of broiler chickens

\begin{tabular}{|c|c|c|c|c|c|}
\hline Parameters & $\begin{array}{l}\text { Diet } 1 \\
\text { Control }\end{array}$ & $\begin{array}{l}\text { Diet } 2 \\
0.25 \% \text { MSM }\end{array}$ & $\begin{array}{l}\text { Diet } 3 \\
0.25 \% \text { SLM }\end{array}$ & $\begin{array}{l}\text { Diet } 4 \\
0.25 \% \text { MSCM }\end{array}$ & $P$ value \\
\hline Slaughtered weight (g/bird) & $2622.66 \pm 93.33$ & $2535.66 \pm 67.33$ & $2471.33 \pm 66.83$ & $2600.33 \pm 115.18$ & 0.63 \\
\hline Dressed weight (g/bird) & $2083.33 \pm 60.09$ & $2036.32 \pm 44.29$ & $1980.00 \pm 39.82$ & $2035.33 \pm 159.93$ & 0.88 \\
\hline Dressing percentage (\%) & $79.47 \pm 0.55$ & $80.33 \pm 0.69$ & $80.17 \pm 1.62$ & $78.09 \pm 3.20$ & 0.82 \\
\hline Liver & $1.61 \pm 0.08$ & $1.55 \pm 0.08$ & $1.57 \pm 0.06$ & $1.73 \pm 0.04$ & 0.34 \\
\hline Heart & $0.41 \pm 0.04$ & $0.38 \pm 0.01$ & $0.55 \pm 0.16$ & $0.43 \pm 0.03$ & 0.53 \\
\hline Lung & $0.47 \pm 0.06$ & $0.48 \pm 0.06$ & $0.38 \pm 0.08$ & $0.57 \pm 0.05$ & 0.34 \\
\hline Pancreas & $0.16 \pm 0.01$ & $0.13 \pm 0.02$ & $0.17 \pm 0.01$ & $0.17 \pm 0.02$ & 0.35 \\
\hline Gall bladder & $0.13 \pm 0.01$ & $0.13 \pm 0.01$ & $0.15 \pm 0.01$ & $0.11 \pm 0.03$ & 0.58 \\
\hline Gizzard and proventriculus & $2.37 \pm 0.20$ & $2.56 \pm 0.15$ & $2.39 \pm 0.31$ & $2.36 \pm 0.14$ & 0.90 \\
\hline Spleen & $0.12 \pm 0.02$ & $0.10 \pm 0.01$ & $0.09 \pm 0.02$ & $0.14 \pm 0.01$ & 0.21 \\
\hline
\end{tabular}

Means within a row with different letters and are significantly different $(P<0.05)$

MSM Myristica fragrans seed meal, SLM Syzygium aromaticum leaf meal, MSCM Myristica fragrans seed meal and Syzygium aromaticum leaf meal composite mix (1:1), SEM standard error of the mean

\section{Meat lipid peroxidation, antioxidant enzymes, and cholesterol}

The result of the effect of SLM, MSM, and MSCM supplement on meat quality of broiler chicken is presented in Table 7. The result revealed significant $(P<0.05)$ differences in lipid oxidation, glutathione peroxidase, and cholesterol content of breast muscle of broiler chicken across treatments, while the concentration of catalase was statistically different $(P>0.05)$ across treatments. The meat lipid peroxidation was significantly $(P<0.05)$ lower in broiler chickens fed with diets supplemented with $0.25 \%$ MSM (9.43 mg MDA/100 g), 0.25\% SLM (4.48 mg MDA/ $100 \mathrm{~g}$ ), and $0.25 \% \mathrm{MSCM}$ (4.13 mg MDA/100 g) compared with broiler chickens on the control diet (14.08 mg MDA/ $100 \mathrm{~g})$. Similarly, the value of catalase was numerically lower in the control diet $(1.98 \mathrm{U} / \mathrm{ml})$ compared with SLM, MSM and MSCM treatments. Meanwhile, broilers fed with control diet had lowered glutathione peroxidase level $(150.83 \mathrm{mg} / \mathrm{ml})$ compared with those fed with diet supplemented with $0.25 \%$ MSM $(284.75 \mathrm{mg} / \mathrm{ml})$, and $0.25 \%$ MSCM $(242.25 \mathrm{mg} / \mathrm{ml})$. The inclusion of SLM, MSM, and
MSCM at $0.25 \%$ in broiler diet significantly reduced the cholesterol level of the meat compared with control (223.75 mg/dl).

\section{Intestinal bacteria of the broiler chickens}

Table 8 shows the result of the intestinal bacteria of the broiler chicken. The analysis revealed no significant difference $(P>0.05)$ in aerobic bacteria, lactic acid-producing bacteria, and intestinal negative bacteria counts except coliform bacteria $(P>0.05)$ counts. Supplementation of $0.25 \%$ SLM significantly decreased coliform bacteria compared with control, while the result of coliform bacteria count of $0.25 \%$ MSM and $0.25 \%$ MSCM was comparable to that of control.

\section{Discussion}

Phytochemical composition and antioxidant activity of Myristica fragrans seed meal and Syzygium aromatic leaf meal

Herbs and spices are considered an important source of phytochemicals that possessed strong antioxidant activity

Table 5 Effects of phytogenic supplements on haematological indices of broiler chickens

\begin{tabular}{|c|c|c|c|c|c|}
\hline Parameters & $\begin{array}{l}\text { Diet } 1 \\
\text { Control }\end{array}$ & $\begin{array}{l}\text { Diet } 2 \\
0.25 \% \text { MSM }\end{array}$ & $\begin{array}{l}\text { Diet } 3 \\
0.25 \% \text { SLM }\end{array}$ & $\begin{array}{l}\text { Diet } 4 \\
0.25 \% \text { MSCM }\end{array}$ & $P$ value \\
\hline Packed cell volume (\%) & $34.00 \pm 1.15$ & $34.50 \pm 0.28$ & $38.00 \pm 1.15$ & $34.50 \pm 2.02$ & 0.19 \\
\hline Red blood cells $\left(\times 10^{12} / \mathrm{l}\right)$ & $3.06 \pm 0.31$ & $2.90 \pm 0.05$ & $2.35 \pm 0.08$ & $2.60 \pm 0.11$ & 0.08 \\
\hline Haemoglobin conc. (g/dl) & $11.20 \pm 0.61$ & $11.50 \pm 0.09$ & $12.66 \pm 0.38$ & $11.50 \pm 0.67$ & 0.24 \\
\hline Mean cell haemoglobin conc. (g/dl) & $32.99 \pm 1.98$ & $33.33 \pm 0.00$ & $33.33 \pm \vee 0.00$ & $33.34 \pm 0.00$ & 0.99 \\
\hline Mean cell volume $(f \mid)$ & $112.50 \pm 8.31^{c}$ & $119.04 \pm 1.37^{b c}$ & $161.81 \pm 1.05^{\mathrm{a}}$ & $132.44 \pm 1.88^{b}$ & 0.01 \\
\hline Mean cell haemoglobin (pg) & $36.96 \pm 2.59^{c}$ & $39.68 \pm 0.45^{c}$ & $53.93 \pm 0.32^{a}$ & $44.14 \pm 0.62^{b}$ & 0.01 \\
\hline White blood cells $\left(\times 10^{9} / \mathrm{l}\right)$ & $3.83 \pm 0.21$ & $3.50 \pm 1.09$ & $2.05 \pm 0.08$ & $3.45 \pm 0.03$ & 0.19 \\
\hline
\end{tabular}

MSM Myristica fragrans seed meal, SLM Syzygium aromaticum leaf meal, MSCM Myristica fragrans seed meal and Syzygium aromaticum leaf meal composite mix (1:1), SEM standard error of the mean

${ }^{\mathrm{abc}}$ Means within a row with different letters and are significantly different $(P<0.05)$ 
Table 6 Effects of phytogenic supplements on serum metabolites and serum antioxidant enzymes of broiler chickens

\begin{tabular}{|c|c|c|c|c|c|}
\hline Parameters & $\begin{array}{l}\text { Diet } 1 \\
\text { Control }\end{array}$ & $\begin{array}{l}\text { Diet } 2 \\
0.25 \% \text { MSM }\end{array}$ & $\begin{array}{l}\text { Diet } 3 \\
0.25 \% \text { SLM }\end{array}$ & $\begin{array}{l}\text { Diet } 4 \\
0.25 \% \text { MSCM }\end{array}$ & $P$ value \\
\hline \multicolumn{6}{|l|}{ Serum metabolites } \\
\hline Creatinine $(\mu \mathrm{mol} / \mathrm{l})$ & $42.91 \pm 11.41$ & $33.70 \pm 1.03$ & $25.80 \pm 0.57$ & $35.50 \pm 4.09$ & 0.33 \\
\hline Aspartate aminotransferase (IU/L) & $74.17 \pm 11.18$ & $76.80 \pm 3.00$ & $81.70 \pm 5.48$ & $98.00 \pm 0.51$ & 0.11 \\
\hline Alanine aminotransferase (IU/L) & $30.18 \pm 0.59$ & $31.76 \pm 0.50$ & $29.44 \pm 2.17$ & $30.44 \pm 0.60$ & 0.60 \\
\hline Cholesterol $(\mu \mathrm{mol} / \mathrm{l})$ & $7.03 \pm 1.00^{\mathrm{a}}$ & $4.17 \pm 0.33^{b}$ & $4.04 \pm 0.26^{b}$ & $4.17 \pm 0.15^{b}$ & 0.01 \\
\hline \multicolumn{6}{|l|}{ Serum antioxidant enzymes } \\
\hline Catalase $(\mathrm{mM} / \mathrm{ml} / \mathrm{min})$ & $5.96 \pm 1.56^{b}$ & $14.97 \pm 1.75^{\mathrm{a}}$ & $8.91 \pm 1.06^{\mathrm{ab}}$ & $13.94 \pm 2.87^{\mathrm{a}}$ & 0.03 \\
\hline Superoxide dismutase (\%) & $76.38 \pm 6.39$ & $78.84 \pm 0.01$ & $73.86 \pm 13.02$ & $82.11 \pm 3.26$ & 0.87 \\
\hline Glutathione peroxidase $(\mu \mathrm{g} / \mathrm{g})$ & $78.68 \pm 9.95^{b}$ & $101.50 \pm 0.28^{\mathrm{ab}}$ & $124.16 \pm 14.43^{\mathrm{a}}$ & $129.70 \pm 11.18^{\mathrm{a}}$ & 0.03 \\
\hline
\end{tabular}

MSM Myristica fragrans seed meal, SLM Syzygium aromaticum leaf meal, MSCM Myristica fragrans seed meal and Syzygium aromaticum leaf meal composite mix (1:1), SEM standard error of the mean

${ }^{\mathrm{ab}}$ Means within a row with different letters and are significantly different $(P<0.05)$

against free radicals in biological systems. Herbs and other phytogens are utilized in poultry and other livestock diets to elicit a wide range of biological activities such as antibacterial, antifungal, antiviral, anti-parasite, and anticoccidiosis (Dhama et al. 2015). The result of the present study showed that both SLM and MSM possessed moderate antioxidant content and activities. The amount of flavonoid, phenolic, terpenoid, and saponin content was higher in MSM than SLM; on the other hand, SLM exhibited more DPPH free radical scavenging activity than MSM. This result is in line with other studies who have reported Myristica fragrans and Syzygium aromatic plants to possess phytochemicals and exhibit strong antioxidant activities (Guptaa et al. 2013; Olaleye et al. 2006; CortesRojas et al. 2014).

\section{Performance of broiler chickens}

The use of herbs, spices, and other phytogens as a feed additive has been demonstrated as an excellent growth enhancer in poultry production. The significant increase in body weight gain (BWG) and feed conversion ratio (FRC) of broilers fed with diets supplemented with MSCM compared with control during finisher stage and overall feeding period could be attributed to the synergetic action of different phytochemicals present in plants as shown in Table 2 above which in turn may have induced greater diet utilization and efficiency (Dhama et al. 2015) thereby promoting growth performance of the experimental birds. Phytochemicals such as flavonoid, phenol, and saponin have been reported to promote higher growth rate and better feed efficiency in domestic birds due to their ability to scavenge free radicals and maintain the integrity of the intestinal mucosa (Oloruntola et al. 2018, 2019). Also, earlier reports had shown that SLM and MSM possessed antibacterial, antiparasite, antifungal, anti-coccidiosis, and hepatoprotective properties (Cortes-Rojas et al. 2014; Olaleye et al. 2006; Panggabean et al. 2019) which are capable of stimulating the growth of beneficial bacterial, inactivate pathogenic bacteria, and facilitate nutrient metabolism and absorption in the gastrointestinal tract (Dhama et al. 2015) to enhance growth performance of broiler chickens. Additionally, the improved FCR observed in broiler chickens fed with diet containing MSCM indicate evidence of better feed utilization than the control group which may be due to increase in secretions of endogenous gastric

Table 7 Effects of phytogenic supplements on the quality of broiler chicken meat

\begin{tabular}{llllll}
\hline Parameters & Diet 1 & Diet 2 & Diet 3 & Diet 4 & $P$ value \\
& Control & $0.25 \% \mathrm{MSM}$ & $0.25 \% \mathrm{SLM}$ & $0.25 \%$ MSCM & 0.03 \\
\hline Lipid peroxidation $(\mathrm{mg} \mathrm{MDA} / 100 \mathrm{~g})$ & $14.08 \pm 0.57^{\mathrm{a}}$ & $9.43 \pm 4.27^{\mathrm{ab}}$ & $4.48 \pm 0.65^{\mathrm{b}}$ & $4.13 \pm 0.18^{\mathrm{b}}$ & $4.53 \pm 0.33$ \\
Catalase $(\mathrm{U} / \mathrm{ml})$ & $1.98 \pm 0.24$ & $5.53 \pm 2.36$ & $5.81 \pm 2.28$ & $242.25 \pm 14.28^{\mathrm{ab}}$ & 0.04 \\
Glutathione peroxidase $(\mathrm{mg} / \mathrm{ml})$ & $150.83 \pm 35.75^{\mathrm{b}}$ & $284.75 \pm 2.16^{\mathrm{a}}$ & $190.86 \pm 39.27^{\mathrm{b}}$ & 240 \\
Cholesterol $(\mathrm{mg} / \mathrm{dl})$ & $223.75 \pm 40.41^{\mathrm{a}}$ & $87.50 \pm 14.43^{\mathrm{b}}$ & $76.59 \pm 8.32^{\mathrm{b}}$ & $124.37 \pm 35.72^{\mathrm{b}}$ & 0.02 \\
\hline
\end{tabular}

MSM Myristica fragrans seed meal, SLM Syzygium aromaticum leaf meal, MSCM Myristica fragrans seed meal and Syzygium aromaticum leaf meal composite mix (1:1), SEM standard error of the mean

${ }^{\mathrm{ab}}$ Means within a row with different letters and are significantly different $(P<0.05)$ 
Table 8 Effects of the phyto-supplements on intestinal microbiology (log10 CFU/g) of broiler chickens

\begin{tabular}{llllll}
\hline Parameters & Diet 1 & Diet 2 & Diet 3 & Diet 4 & $P .25 \%$ MSCM \\
\hline Aerobic bacteria & Control & $0.25 \%$ MSM & $0.25 \%$ SLM & $5.72 \pm 0.13$ & 0.13 \\
Lactic acid-producing bacteria & $5.12 \pm 0.12$ & $5.26 \pm 0.28$ & $4.85 \pm 0.31$ & $6.02 \pm 0.06$ \\
Coliform bacteria & $5.87 \pm 0.07$ & $5.73 \pm 0.18$ & $5.91 \pm 0.09$ & $5.11 \pm 0.64^{\mathrm{a}}$ & 0.01 \\
Intestinal negative bacteria & $4.89 \pm 0.51^{\mathrm{a}}$ & $5.13 \pm 0.65^{\mathrm{a}}$ & $1.91 \pm 0.45^{\mathrm{b}}$ & $5.63 \pm 0.10$ \\
\hline
\end{tabular}

MSM Myristica fragrans seed meal, SLM Syzygium aromaticum leaf meal, MSCM Myristica fragrans seed meal and Syzygium aromaticum leaf meal composite mix $(1: 1), S E M$ standard error of the mean

${ }^{\mathrm{ab}}$ Means within a row with different letters and are significantly different $(P<0.05)$

enzymes that facilitate nutrient digestion and fast gut passage rate (Jamroz et al. 2006; Valenzuela-Grijalva et al. 2017). Other studies have revealed that herbs including other plant materials can improve the apparent ileal digestibility of nutrients (Amad et al. 2011). Conversely, reports on the effect of MSM supplementation in poultry diet on growth parameters are very rare.

\section{Carcass traits and relative internal organs of broiler chickens}

Apart from impacting changes on growth performance, herbs and phytogens have been reported to exert positive influences on the development of carcass traits, internal organs, and meat qualities of broiler chickens (Oloruntola et al. 2018). Results on carcass traits and relative internal organs weights of broiler chickens were not significantly affected by the treatments indicating that supplementation of SLS, MSM, and MSCM did not influence the development of muscle and organ compared with control. A similar result has been reported by Tariq et al. (2015) who found no significant effect of supplementing clove powder at $0.5 \%$ relative organ weight of quail birds. On the contrary, Al-Mufarrej et al. (2019a, 2019b) reported higher liver percentage and lower intestine weight of broiler chickens fed a diet containing clove powder compared with control.

\section{Haematological indices of broiler chickens}

Application of herbs has been observed to improve health and well-being of the animal because of their ability to acts as immune stimulants by stimulating and modulating the production of blood cells and other haematological indices and immune responses to alleviate diseases (Dhama et al. 2015; Anjusha et al. 2019). The results on packed cell volume, red blood cells, haemoglobin, mean cell haemoglobin concentration, and white blood cells were not significantly different across treatments, although were numerically higher in birds supplemented with SLS, MSM, and MSCM compared with control. This observation, however, confirms the nutritional adequacy and safety of the diets supplemented with SLM, MSM, and MSCM in supporting the normal haemapoietic process of the broiler chickens
(Oloruntola et al. 2019). Contrary to the present findings, Oloruntola et al. (2019) reported significant variation in packed cell volume, red blood cells, haemoglobin, mean cell haemoglobin concentration, and white blood cells of broiler chickens fed with different phytoadditives. Conversely, significant differences were observed in the values obtained for mean cell volume and mean cell haemoglobin across the treatments. The significant increase in mean cell volume and mean cell haemoglobin contents recorded for broiler chickens fed a diet containing SLM and MSM compared with control is evidence of the production of more oxygenated red blood cells in the tissue since haemoglobin is found in red blood cells as the protein that is responsible for the delivery of oxygen to the tissues. Herbs and phytogens that can exert hepato-stimulatory and hepatoprotective effects have been reported to stimulate syntheses of more hematoglobin in the bone marrow, thereby increasing the hematoglobin circulation in the tissue (Dhama et al. 2015) as seen in the present study.

\section{The serum metabolites and serum antioxidant enzyme of the broiler chickens}

Findings from this study show no significant influence of SLS, MSM, and MSCM supplements on serum creatinine, aspartate aminotransferase, alanine aminotransferase, and superoxide dismutase of the broiler chicken. In comparison with the control group, the inclusion of SLM, MSM, and MSCM in the broiler diets significantly lowered the serum cholesterol level, but increased the catalase, and glutathione peroxidase content. Cholesterol is a type of lipid that is found in the body as part of lipoproteins. Excessive accumulation of cholesterol in the body has been associated with cardiovascular disease, causing the blockage of artery walls and reduction in blood flow to the heart (Oloruntola et al. 2018). The observed decrease in serum cholesterol level of broiler chicken supplemented with SLS and SMS suggests their hypo-cholesterolemic activity which could be due to their ability to delay intestinal absorption of dietary fat by inhibiting pancreatic lipase activity when applied in poultry diet. Gaurav (2015) in their study have reported a reduction in serum total cholesterol level of broiler fed with diet containing herbs 
(Chlorophytum root and Camellia seed). Similarly, catalase has been reported as one of the important antioxidant enzymes that inactivate, scavenge, and remove free radical and other reactive species in the tissue to protect the body against oxidative stress (Delles et al. 2014). The observed increase in serum catalase and glutathione peroxidase content of broiler chicken supplemented with SLS, MSM, and MSCM indicate their ability to stimulate the production of more endogenous antioxidant enzymes to fight free radicals and protect the cell molecules against hydrogen lipid peroxidation and peroxide toxicity (Oloruntola et al. 2018). These findings are in agreement with the report of Kostadinović et al. (2015) and Daramola (2019) who found that the addition of herbal plants in the boiler diet significantly enhanced the concentration of catalase compared with control group.

\section{Meat lipid peroxidation, antioxidant enzymes, and cholesterol}

Herbal plants and other phytogens have been demonstrated as a natural source of antioxidant in poultry diets. As a natural antioxidant, they can donate hydrogen ions to inhibit the free radical formation and/or interrupt propagation of lipid oxidation in the muscle (Falowo et al. 2014) or increase the production of different endogenous enzymes such as catalase, superoxide dismutase, and glutathione peroxidase (Dhama et al. 2015). Results from this study revealed a significant decrease in lipid peroxidation and cholesterol levels and a surge increase in glutathione peroxidase concentrations in breast meat of broilers supplemented with SLM, MSM, and MSCM compared with control. The potential of SLM, MSM, and MSCM to decrease the level of lipid oxidation in meat samples could be attributed to the presence of inherent phytochemicals and antioxidant activity (Table 1) to inhibit the production of free radicals and prevent oxidative damages. Besides, the higher amount of glutathione peroxidase concentration of broiler chickens receiving SLM and MSCM could be responsible for the decrease in lipid peroxidation recorded in this study. The glutathione peroxidase is an important antioxidant enzyme that inactivate, scavenge, and remove free radical and other reactive species in the tissue to protect the body against peroxidation and oxidative damages. Another study has reported the capacity of herbal plants to reduce lipid oxidation and increase endogenous antioxidant enzymes in muscle food due to inherent bioactive components and antioxidant activity (Hashemi and Davoodi 2010; Valenzuela-Grijalva et al. 2017). The amount of total cholesterol in the breast muscle was significantly lowered by the supplementation of SLM, MSM, and MSCM compared with control. It is known that regular consumption of food products that contain high cholesterol content can lead to hypercholesterolemia which has been implicated in causing atherosclerosis and coronary heart diseases (Walker et al. 2005). This result is in line with other evidence that has shown that the addition of phyto-additives in broiler diets can significantly inhibit hypercholesterolemia and lower cholesterol level in muscle food due to the inherent bioactive compounds (Onyimonyi et al. 2012; Nabil Alloui et al. 2014; Yilkal 2015; Puvaca et al. 2015).

\section{Intestinal bacteria of the broiler chickens}

The result of the intestinal bacteria count revealed that the inclusion of SLM significantly reduced the coliform bacteria count, while the dietary effect of MSM and MSCM on coliform bacteria counts was comparable to that of control. On the other hand, the result of the total aerobic bacteria, lactic acid-producing bacteria, and intestinal negative bacteria counts was similar across the treatments thereby suggesting that SLM and MSM dietary supplementation could maintain or preserve the intestinal microflora throughout the feeding trial. Several studies have shown that maintenance of non-pathogenic intestinal bacteria is essential for the inhibition of pathogen proliferation, enhancement of growth performance, and reduction of morbidity and mortality of broiler production (Seidavi and Simoes 2015; Oloruntola et al. 2019). This result is consistent with the report of Oloruntola et al. (2019) who found that the addition of phyto-additive did not significantly influence the caecum microflora of the boiler chicken.

\section{Conclusions}

Findings of the present study reveal the potential of Myristica fragrans seed meal (MSM) and Syzygium aromaticum leaf meal (SLM) to enhance growth performance, health, and meat quality of broiler chickens when used as a phytogenic feed supplement. It was shown that the inclusion of MSCM at $0.25 \%$ can improve body weight gain and endogenous antioxidant enzymes, maintain carcass traits, organ weight, and gut microflora and reduce meat cholesterol and lipid oxidation of broiler chickens. Further research is required to assess MSM and SLM effects on immune responses and the meat fatty acid profile of broiler chickens.

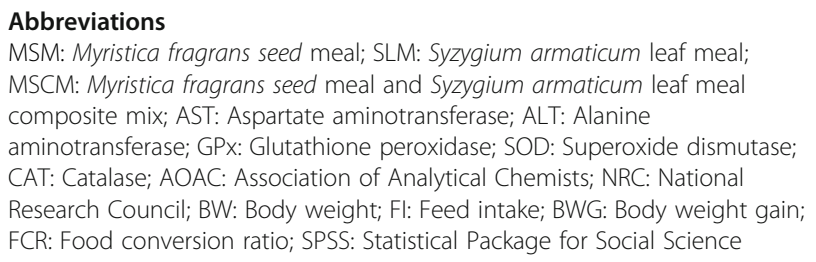

Acknowledgements

Not applicable 


\section{Authors' contributions}

OAA, FAG, and ODO designed the research study. OAA, ODO, FAG, ABF, and OJO managed all activities of the experiment collectively. OAA, FAG, and ODO collected the birds' performance data. OAA, ODO, ABF, and OJO analyzed the data and interpreted the data. All authors gathered referenced materials. ABF and ODO prepared the first draft of the manuscript. All authors reviewed the first draft of the manuscript and approved the final manuscript.

\section{Funding}

This research was not funded by any organization or institution.

\section{Availability of data and materials}

The datasets used and/or analyzed during the current study are available from the corresponding author on reasonable request.

\section{Ethics approval and consent to participate}

All animal experimental protocols were approved by the Research and Ethics Committee of the Animal Science Department, Faculty of Agriculture, Adekunle Ajasin University, Akungba Akoko, Nigeria.

\section{Consent for publication}

\section{Not applicable}

\section{Competing interests}

The authors declare that they have no competing interests.

\section{Author details}

${ }^{1}$ Animal Science Department, Adekunle Ajasin University, Akungba Akoko, Nigeria. ${ }^{2}$ Animal Production and Health Department, The Federal University of Technology, Akure, Nigeria.

\section{Received: 22 April 2020 Accepted: 13 August 2020}

Published online: 07 September 2020

\section{References}

Aebi H (1974) Catalase estimation. In: Bergmeyer HV (ed) Methods of enzymatic analysis. Verlag Chemic. New York Academic Press, New York

Agbogidi OM, Azagbaekwe OP (2013) Health and nutritional benefits of nutmeg (Mystica fragrans houtt). Sci Agri 1(2):40-44

Allain CC, Poon LS, Chan CSG, Richmond W, Fu PC (1974) Enzymatic determination of total serum cholesterol. Clinical Chem 20(Suppl 4):470-475

Al-Mufarrej SI, Al-Baadani HH, Fazea EH (2019a) Effect of level of inclusion of clove (Syzygium aromaticum) powder in the diet on growth and histological changes in the intestines and livers of broiler chickens. South African J Anim Sci 49(1):166-175

Al-Mufarrej SI, Fazea EH, Al-Baadani HH, Qaid MM (2019b) Effects of clove powder supplementation on performance, blood biochemistry, and immune response in broiler chickens. South African J Anim Sci. 49(5). https://doi.org/ 10.4314/sajas.v49i5.6

Amad AA, Männer K, Wendler KR, Neumann K, Zentek J (2011) Effects of a phytogenic feed additive on growth performance and ileal nutrient digestibility in broiler chickens. Poult Sci 90:2811-2816

Anjusha KV, Mamun MAA, Dharmakar P, Shamima N (2019) Effect of medicinal herbs on hematology of fishes. Int J Current Microbiol Appl Sci 8(9):23712376

Bhowmik D, Kumar KPS, Yadav A, Srivastava S, Paswan S, Dutta SS (2012) Recent trends in Indian traditional herb Syzygium aromaticum and its health benefits. J Pharmacog Phytochem 1(1):1-23 www.phytojournal.com

Bohm BA, Kocipai-Abyazan C (1994) Flavonoids and condensed tannin from leaves of Hawaiian Vaccinium vaticulatum and V. calycinium. Pacific Sci 48 458-463

Botsoglou NA, Fletouris DJ, Papageorgiou GE, Vassilopoulos VN, Mantis AJ, Trakatellis A (1994) Rapid, sensitive, and specific thiobarbituric acid method for measuring lipid peroxidation in animal tissue, food, and feedstuff samples. J Agric Food Chem 42:1931-1937

Brunner JH (1984) Direct spectrophotometer determination of saponin. Anim Chem 34:1324-1326

Cichoski AJ, Rotta RB, Scheuermann G, Cunha Junior A, Barin JS (2012) Investigation of glutathione peroxidase activity in chicken meat under different experimental conditions. Ciência e Tecnologia de Alimentos 32(Suppl 3):661-167

Cortes-Rojas DF, de Souza CR, Oliveira WP (2014) Clove (Syzygium aromaticum): a precious spice. Asian Pac J Trop Biomed 4(2):90-96

Daramola OT (2019) Medicinal plants leaf meal supplementation in broiler chicken diet: effects on performance characteristics, serum metabolite, and antioxidant status. Animal Research International 16(2):3334-3342

Delles RM, Xiong YL, True AD, Ao T, Dawson KA (2014) Dietary antioxidant supplementation enhances lipid and protein oxidative stability of chicken broiler meat through promotion of antioxidant enzyme activity. Poultry Sci 93:1561-1570

Dhama K, Latheef SK, Mani S, Samad HA, Karthik K, Tiwari R, Khan RU, Alagawany M, Faraq MR, Alam GM, Laudadio V, Tufarelli V (2015) Multiple beneficial applications and modes of action of herbs in poultry health and production-a review. Int J Pharmacol 11:152-176. https://doi.org/10.3923/ ijp.2015.152.176

Dorman, HJ, Deans, SG (2000) Antimicrobial agents from plants: Antibacterial activity of plant volatile oils. J Appl Microbiol 88: 308-316.

Falowo AB, Fayemi PO, Muchenje V (2014) Natural antioxidants against lipidprotein oxidative deterioration in meat and meat products: a review. Food Res Int 64:171-181. https://doi.org/10.1016/j.foodres.2014.06.022

Gaurav AK (2015) Studies on supplementation of Chlorophytum root and Camellia seed as feed additives in broiler ration. M.V.Sc. Thesis, Deemed University, Indian Veterinary Research Institute, Izatnagar, pp 50-61

Guptaa AD, Bansal VK, Babu V, Maithil N (2013) Chemistry, antioxidant and antimicrobial potential of nutmeg (Myristica fragrans Houtt). J Genetic Eng Biotechnol 11(1):25-31

Gyamfi MA, Yonamine M, Aaniya Y (1999) Free radical scavenging action of medicinal herbs from Ghana: Thonningia sanguine on experimentally induced liver injuries. Gen Pharmacol 32:661-667

Hadwan M, Khabt H (2018) Simple spectrophotometric method for analysis of serum catalase activity. J Clin Diag Res 12(Suppl 9):13-16

Hashemi SR, Davoodi H (2010) Phytogenics as new class of feed additive in poultry industry. J Anim Vet Adv 9:2295-2304

Ignat I, Volf I, Popa VI (2013) Analytical methods of phenolic compounds. In: Ramawat K, Mérillon JM (eds) Natural Products. Springer, Berlin, Heidelberg

Jamroz D, Wertelecki T, Houszka M, Kamel C (2006) Influence of diet type on the inclusion of herbal origin active substances on morphological and histochemical characteristics of the stomach and jejunum walls in chicken. J Anim Physiol Anim Nutr 90:255-268

Kostadinović L, Lević J, Popović S, Čabarkapa I, Puvača N, Đuragić O, Kormanjoš S (2015) Dietary inclusion of Artemisia absinthium for management of growth performance, antioxidative status and quality of chicken meat. Europ Poult Sci:79. ISSN 1612-9199. https://doi.org/10.1399/eps.2015.75

Mahrous HB, El-far AH, Sadek KM, Abdel-Latif MA (2017) Effects of different levels of clove bud (Syzygium aromaticum) dietary supplementation on immunity, antioxidant status, and performance in broiler chickens. Alexandria J Vet Sci. 54(2):29-39 www.alexjvs.com

Misra HP, Fridovich I (1972) The univalent reduction of oxygen by flavins and quinines. J Biol Chem 247:188-192

Morita T, Jinno K, Kawagishi H, Arimoto Y, Suganuma H, Inakuma T, Sugiyama K (2003) Hepatoprotective effect of myristicin from nutmeg (Myristica fragrans) on lipopolysaccharide/d-galactosamine-induced liver injury. J Agric Food Chem 51(6):1560-1565

Nabil Alloui M, Agabou A, Alloui N (2014) Application of herbs and phytogenic feed additives in poultry production: a review. Global J Anim Scientif Res 2:234-243

Nadkarni KM (2000) Myrtus caryophyllus. In: K.M. Nadkarni (ed). Materia medica. Popular Prakashan Pvt. Ltd., Mumbai, India 2, 835-836.

NRC (1994) Nutrient requirements of poultry (9th Revised ed.). National Academy Press, Washington

Olaleye MT, Akinmoladun AC, Akindahunsi AA (2006) Antioxidant properties of Myristica fragrans (Houtt) and its effect on selected organs of albino rats. African J Biotechnol 5(13):1274-1278

Oloruntola OD, Agbede JO, Ayodele SO, Oloruntola DA (2018) Neem, pawpaw, and bamboo leaf meal dietary supplementation in broiler chickens: effect on performance and health status. J Food Biochem:e12723. https://doi.org/10. $1111 /$ jfbc. 12723

Oloruntola OD, Ayodele SO, Adeyeye SA, Jimoh AO, Oloruntola DA, Omoniyi SI (2019) Pawpaw leaf and seed meals composite mix dietary supplementation: effects on broiler chicken's performance, caecum microflora, and blood 
analysis. Agroforestry Syst 94:555-564. https://doi.org/10.1007/s10457-01900424-1

Onyimonyi AE, Chukwuma PC, Igbokwe C (2012) Growth and hypocholesterolemic properties of dry garlic powder (Allium sativum) on broilers. African J Biotechn 11(11):2666-2671

Panggabean KA, Rusmarilin H, Suryanto D (2019) The utilization of nutmeg seed (Myristica fragrans Houtt) extract as an antimicrobial on tempeh sausage. Earth Environ Sci 260:012087. https://doi.org/10.1088/1755-1315/260/1/ 012087

Periasamy G, Karim A, Gibrelibanos M, Gebremedhin G, Gilani A (2016) Nutmeg (Myristica fragrans Houtt) oils. In: Preedy V R (Ed.), Essential oils in food preservation, flavour, and safety. Academic Press, First Edition, Chapter 69, pp. 607-616. http://www.elsevier.com/locate/permissionusematerial

Puvaca N, Kostadinovic L, Popovic S, Levic JD, Ljubojevic D, Tufarelli V, Jovanovic R, Tasic T, Ikonic P, Lukac D (2015) Proximate composition, cholesterol concentration and lipid oxidation of meat from chickens fed dietary spice addition (Allium sativum, Piper nigrum, Capsicum annuum). Anim Prod Sci. 56(11):1920-1927

Rotruck JT, Pope AL, Ganther HE, Hafeman DG, Hoekstra WG (1973) Selenium: biochemical role as a component of glutathione peroxidase. Sci 179:588-590. https://doi.org/10.1126/science.179.4073.588

Seidavi A, Simoes J (2015) Evaluation of dietary fish oil plus green tea supplementation on the gizzard, ileum and cecum microflora in broiler chickens. Arch Zootec 64:397-402

Sharma A, Mathur R, Dixit VP (1995) Prevention of hypercholesterolemia and atherosclerosis in rabbits after supplementation of Myristica fragrans seed extract. Indian J Physiol Pharmacol 39:407-410

Shastry GA (1983) Veterinary clinical pathology, 2nd edn. CBS Publishers and Distributors, New Delhi, India

Sofowora A (1993) Medicinal plants and traditional medicine in Africa. Spectrum Books Ltd., Ibadan, Nigeria

Sulieman AME, Elboshra IMO, Elkhalifa EAA (2007) Nutritive value of clove (Syzygium aromaticum) and detection of antimicrobial effect of its bud oil. Res J Microbiol 2(3):266-271

Tariq H, Raman Rao PV, Raghuvanshi RS, Mondal BC, Singh SK (2015) Effect of aloe vera and clove powder supplementation on carcass characteristics, composition and serum enzymes of Japanese quails. Vet World. 8:664 www. veterinaryworld.org/Nol.8/May-2015/19.pdf

Valenzuela-Grijalva NV, Pinelli-Saavedra A, Muhlia-Almazan A, Domínquez-Díaz D, González-Ríos H (2017) Dietary inclusion effects of phytochemicals as growth promoters in animal production. J Anim Sci Tech 59:8

Walker P, Rhubart-Berg P, McKenzie S, Kelling K, Lawrence RS (2005) Public health implications of meat production and consumption. Public Health Nutr 8:348-356

Yakaiah V, Dakshinamoorthi A, Kavimani S (2019) Effect of Myristica fragrans extract on total body composition in cafeteria diet-induced obese rats. Bioinformation 15(9):657-665

Yilkal T (2015) Important anti-nutritional substances and inherent toxicants of feeds. Food Sci Quality Manag 36:40-47

Zakaria MPM, Abas F, Rukayadi Y (2015) Effects of Myristica fragrans Houtt. (Nutmeg) extract on chemical characteristics of raw beef during frozen storage. Int Food Res J 22(3):902-909

\section{Publisher's Note}

Springer Nature remains neutral with regard to jurisdictional claims in published maps and institutional affiliations.

\section{Submit your manuscript to a SpringerOpen ${ }^{\circ}$ journal and benefit from:}

- Convenient online submission

- Rigorous peer review

- Open access: articles freely available online

- High visibility within the field

- Retaining the copyright to your article

Submit your next manuscript at $\boldsymbol{\nabla}$ springeropen.com 